\title{
Mirosław Dzień
}

Akademia Techniczno-Humanistyczna w Bielsku-Białej

University of Bielsko-Biała

mdzien@ath.bielsko.pl

\section{KATEGORIA „NIEWYRAŻALNEGO” \\ W DYSKURSIE KRYTYCZNOLITERACKIM: \\ (RYSZARD KRYNICKI, KRYSTYNA MIŁOBĘDZKA, JULIAN KORNHAUSER, MARCIN ŚWIETLICKI)

\author{
THE CATEGORY OF „INEXPRESSIBLE” \\ IN CRITICAL LITERARY DISCOURSE: \\ (RYSZARD KRYNICKI, KRYSTYNA MIŁOBĘDZKA, \\ JULIAN KONRHAUSER, MARCIN ŚWIETLICKI).
}

Szkic podejmuje próbę opisania kategorii „niewyrażalnego” na styku dyskursu krytycznoliterackiego i teologicznego. Analizie poddane zostały utwory: Ryszarda Krynickiego, Krystyny Miłobędzkiej, Juliana Kornhausera i Marcina Świetlickiego. W analizowanych wierszach przywołać możemy szerszy kontekst interpretacyjny obejmujący filozofię dialogu Martina Bubera, żydowską kabałę oraz mistykę Mistrza Eckharta. Niewyrażalne wydaje się być pojęciem archetypicznym, istniejącym w innym porządku ontycznym i aksjologicznym. Niewyrażalne można lokować w sferze szeroko pojmowanego sensu mistycznego. Niewyrażalne pojawia się zawsze jako „naddatek” wyrażalnego; jako forma uzupełnienia świata. To zaś domaga się dyskursu intuicyjnego; próby budowania wciąż pełniejszych przybliżeń. Kategoria „niewyrażalnego” okazuje się pojęciem niedefiniowalnym, aporetycznym, w którym mieści się tajemnica sensu.

Słowa kluczowe: niewyrażalne, mistyka, filozofia, kabała żydowska.

The sketch attempts to describe the category „inexpressible” at the meaning point of critical literary and theological discourse. The pieces were analyzed Ryszard Krynicki, Krystyna Miłobędzka, Julian Kornhauser and Marcin Świetlicki. In the poems analysed, we can recall a broader interpretative context covering Martin Buber's philosophy of dialogue, the Jewish Kabbalach and Master Eckhart's mysticism. The inexpressible seems to be an archetypical concept, existing in a different ontological and axiological order. The inexpressible can be located in the sphere of broadly understood mystical sense. The inexpressible always appears as a "surplus"; of the expressive; as a form of complementing world. This, in turn, calls for an intuitive discourse; an attempt to built ever more complete close-ups. The category of the "inexpressible" turns aut to be an undefined, aporetic notion that contains the mystery of meaning.

Key words: inexpressible, mystical sense, philosophy, Jewish Kabbalah. 
Prezentowany szkic potraktować należy, jako przyczynek do krytycznoliterackiej i filozoficznej, a także teologicznej dyskusji na temat „niewyrażalnego". Piszący te słowa ma świadomość, iż temat „niewyrażalnego” w pewien specyficzny sposób posiada historię równoległą do historii człowieka, który za pomocą mowy zdecydował się komunikować ze światem, innym człowiekiem, trancendensem i samym sobą. W ten sposób kategoria „niewyrażalnego" stała się jedną z prymarnych kategorii w duchowym rozwoju człowieka, i w szeroko rozumianej kulturze. Ta ostatnia zaś w jakimś stopniu stanowi fascynujący proces zbliżania się do „niewyrażalnego”.

W krytycznoliterackim dyskursie ostatnich ponad dwudziestu lat na szczególną uwagę zasługuje konferencja z 1996 roku poświęcona literackim kontekstom „niewyrażalnego"1. Wówczas, w połowie lat dziewięćdziesiątych ubiegłego stulecia, był to temat względnie nowy, mało eksplorowany przez literaturoznawców ${ }^{2}$. Poszukując genezy pojęcia niewyrażalnego sięgnąć należy do krytyki XIX wiecznego paradygmatu naukowego i wpisanej weń koncepcji języka i metodologii. To wtedy zakwestionowano możliwość dyskursywnego ujmowania rzeczywistości ludzkiej. Prace Diltheya, Bergsona i Wittgensteina w dużym stopniu przyczyniły się do innego sposobu postrzegania świata i języka, ze słynną formułą ostatniego z nich, iż „Granice mojego języka oznaczają granice mego świata" 3 (Wittgenstein 2000: 64). Konsekwencją takiego stanowiska jest przekonanie, że poznanie jest poza językiem, a język może jedynie odsyłać do niewyrażalnych przestrzeni. Na tej granicy wyraża się ,sens”. Z drugiej jednak strony odwołując się do filozofii Emmanuela Levinasa, Nelly Przybylska zauważa: „,język> odzwierciedla relacje z drugim człowiekiem, a jednocześnie jest też warunkiem ukonstytuowania tejże relacji. Skoro język pozwala przekroczyć próg samego siebie i tym samym dostrzec człowieka, ten sam język jest nadzieją nieskończoności”4 (Przybylska 2011: 101-102).

Kategoria niewyrażalnego wydaje się być jedną z tych, wobec których komentator staje się bezsilny. I jest to bezsiła wielowymiarowa. „Niewyrażalne" nie jest bowiem ani niewyraźnym, ani nie wyrażonym. Stanowi raczej osobną kategorię; jest, jak ujmuje to Edward Balcerzan ,powiadomieniem o aktywności duchowej człowieka"5 (Balcerzan 1997: 5); jest też na swój spo-

1 Mam na myśli XXVI Konferencję Teoretycznoliteracką pt. „Literatura wobec niewyrażalnego". Międzyzdroje, wrzesień 1996.

2 Pokłosiem konferencji był szereg artykułów poświęconych zagadnieniu „niewyrażalnego” zwłaszcza na łamach „Tekstów Drugich” w 1997 roku.

3 Tractatus logico-philosophicus, (Wittgenstein 2000: 64).

4 Ujrzeć niewyrażalne: o językowej etyce u Levinasa,(Przybylska 2011: 101-102).

5 Poznański krytyk powiada: „Niepoznawalne, niewyobrażalne, nieprzekładalne. Pojęcia te - podobnie jak niew yrażalne - są powiadomieniami o aktywności duchowej człowieka, która co prawda kończy się porażką (epistemologiczną, imaginacyjną, translatorską, autorską), ale jest to porażka honorowa, bo - uwarunkowana okolicznościami, na które nie mamy wpływu". Niewyrażalne czy nie wyrażone?, (Balcerzan 1997: 5). 
sób zamknięte w obrębie własnych dobrze strzeżonych granic, jak herbertowski kamyk.

W tym miejscu pozwolę sobie przedstawić własne rozpoznanie w kwestii „niewyrażalnego", zastrzegając zarazem iż nie rości sobie ono prawa do bycia wyczerpującym, czy też ujmujących wszystkie jego treściowe aspekty6(zob. też Kluba 1997: 117).

Po pierwsze niewyrażalne jest nie-do-wyrażenia, a zatem niemożliwe do słownego (czy też każdego) innego ujawnienia; intersubiektywnej prezentacji; rozumiejącego i zrozumiałego wyrazu.

Po drugie niewyrażalne zdaje się być także archetypicznym, to znaczy w jakimś sensie wzorcotwórczym; istniejącym w uprzednim, przedustawnym porządku ontycznym i aksjologicznym.

Po trzecie kategoria niewyrażalnego zmierza do wyczerpania; jest na „,skraju sensu”, i na „skraju” języka pragnącego ów sens wyrazić.

Po czwarte wraz z niewyrażalnym przychodzi do nas tajemnica; sekret sensu; ukryte znaczenie niemożliwe do zwerbalizowania; żyjące życiem ukrytym, sekretnym.

Po piąte kłopot z niewyrażalnym nie jest jedynie semantycznym kłopotem tego-co-nie-mieści-się-w-języku, lecz raczej trudnością świata, jako takiego; jest trudnością ontyczną, w której strukturę wpisane jest ,inne”, zasadniczo obce zrozumieniu, albo też owo zrozumienie tak dalece utrudniające, że pozostające na marginesie, w rejonach mętnych, poznawczo dziewiczych, jawiących się niewyraźnie, jak we mgle i tylko w „przeczuciu”, w intuicji, nagłej iluminacji mogące się na moment ujawnić. Już samo nagromadzenie metafor czyni z „niewyrażalnego” krainę niedostępną, a jednak przeczuwaną, jakby doświadczaną w inny, niż przyjęte sposoby rozumienia i wyrażania.

Po szóste niewyrażalne słusznie lokować możemy w sferze szeroko pojmowanego doświadczenia mistycznego. Tam bowiem, gdzie rozum doprowadzony zostaje do skraju swoich kompetencji, tam pojawia się niewyrażalne. I co ciekawe pojawia się ono zawsze, jako „naddatek” wyrażalnego; jako jakaś forma uzupełnienia świata; poszerzenia rzeczywistości o rejony ,inne”, choć zawsze do tejże rzeczywistości należące. W ten sposób „niewyrażalne” uchodząc spod kompetencji dyskursu podlegającego logicznym prawidłom nie tylko zyskuje nowy, inny, niepodległy rzec można status metodologiczny, ale

6 W tym miejscu warto przypomnieć konstatacje Agnieszki Kluby na temat wielu postaci kategorii niewyrażalnego: 1). Okazuje się nie wyrażeniem tego, co jest możliwe do wyrażania, tzn. tego, co nie wyrażone pod groźbą różnego rodzaju sankcji; 2) przypisana zostaje podmiotowi twórczemu, a tym samym uzależniana od jego woli, kontroli i możliwości (lub ich braku); 3) sprowadza się ją do chwytu retoryki i poetyki; 4) sytuuje się ją na poziomie samego tekstu, jako obszar swoistego „nie-tekstu” (według. określenia Łotmana); 5) dostrzega się w niej językowy analogon nierozstrzygalności Godla, przyrodzoną, nieusuwalną przypadłość każdego projektu komunikacyjnego; 6) podaje się ją za główną przyczynę niefortunności każdej interpretacji; 7) nie ma niczego takiego jak niewyrażalność. Por. (Do)wolność niewyrażalności, (Kluba 1997: 119). 
rości sobie prawo do równego traktowania w wyjaśniania świata. Chce - jeśli można tak powiedzieć - na równych prawach odpowiadać za Prawdę o rzeczywistości. Chce być tej Prawdy częścią, może nawet jej rdzeniem, nerwem?

Dlaczego piszę o tych — skądinąd oczywistych rzeczach — otóż dlatego, iż współczesna poezja polska zna wiele przykładów wierszy, które można zaklasyfikować do penetrujących granice niewyrażalnego; czy też do zbliżających się w rejony niewyrażalnego. Granice są tutaj nieostre, gdyż sama kategoria niewyrażalnego, jak zauważyliśmy, nie poddaje się łatwej i nie budzącej jakichkolwiek wątpliwości analizie ${ }^{8}$. Pozostać zatem musimy w sferze dyskursu intuicyjnego; próby budowania przybliżeń. Wciąż przerzucanych kładek, po których przechodzić będziemy nad przepaściami ciemności w nadziei, że na końcu dane nam będzie dosięgnąć światła.

\section{1.}

Jako przykład poezji zbliżającej się w rejony niewyrażalnego wybrałem kilka utworów, o których chciałbym powiedzieć parę słów.

Pierwszy z nich, to wiersz Krystyny Miłobędzkiej z tomu „Gubione”:

$* * *$

każde Ty mocniejsze ode mnie

(Miłobędzka 2008: 18)

Wiersz na pierwszy rzut oka zawiera mocne stwierdzenie odwołujące się sytuacji dialogu (przywołującego słynne określenie Martina Bubera $<$ Ja-Ty $>$ ),

7 Pomocne w tym miejscu mogą być uwagi Edwarda Balcerzana o wielowymiarowym charakterze „niewyrażalnego”. Uczony zauważa: „Badacz, który sądzi iż literatura stanowi emanację mitu, mapę archipelagu archetypów, lub sposób uprawiania metafizyki, będzie szukał dramatu niewyrażalności tam, gdzie kończy się wiedza, a zaczyna wiara, gdzie kończy się znane, zaczyna nieznane: sacrum, transcendencja, tajemnica. Z kolei badacz, który z polu obserwacji, pragnie mieć przede wszystkim systemy kultury, będzie pojmował [...] niewyrażalność jako daremność przekładu intersemiotycznego, czyli niezdolność powtórzenia efektu malarskiego w muzyce, muzycznego w literaturze, literackiego w rzeźbie etc. I wreszcie, lingwistyczne orientacje w teorii literatury, rozwijające idee semantyki Humboldta, mają wystarczająco dowodów, iż co bywa wyrażalne w jednym, często nie da się nijak wyrazić w innym języku naturalnym [...]”. Niewyrażalne czy nie wyrażone?, (Balcerzan 1997: 7).

8 Powrócę raz jeszcze do artykułu Agnieszki Kluby. Badaczka zauważa: ,[...] istnieją dwa rodzaje podejścia do niewyrażalnego: 1) jako do tego, co nie wyrażone z powodu takich lub innych trudności lub sankcji, ale poddające się rekonstrukcji, a przynajmniej tematyzacji na podstawie tekstu, oraz 2) jako do tego, co w sposób przyrodzony nie poddaje się żadnej próbie uprzedmiotowienia i semantyzacji. Ci, którzy mówią o niewyrażalności w odniesieniu do konkretnego tekstu, nie mylą się tak długo, póki nie starają się wykazać, że jego przedmiot jest w pewien uprzywilejowany sposób na nią podatny i nie negują tym samym uniwersalnego charakteru niewyrażalności, przypisanej — zawsze na swój sposób — do każdego projektu komunikacyjnego. (Do)wolność niewyrażalności, (Kluba 1997: 128-129). 
w którym interlokutor zajmuje silniejszą (mocniejszą) pozycję od podmiotu („ode mnie”). Owo „ty” zwielokrotnia się, w jakiś sposób nabiera cech monumentalnych. Już nie jest „zwyczajnym” — „ty”, ale „każdym” ty; nabiera cech ogólnych, gatunkowych, jeśli nie opresyjnych. W takiej konfrontacji ,ja” musi ulec; musi odnaleźć samego siebie, jako byt słabszy, podległy... Ale to nie wszystko. Użycie przez poetkę wielkiej litery jeszcze bardziej komplikuje sprawę. Oto bowiem „ty” nie jest już tylko „ty”, nawet pomnożonym, zwielokrotnionym i w tej wielokrotności podniesionym do potęgi „n-tej”, ale ujawnia swoje boskie właściwości — jest „Ty”. A zatem jego zwielokrotnienie wydaje się przybierać rozmiary kosmiczne; jest konfrontacją bytu przygodnego - ,ja" z bytem Absolutnym — „Ty”. Wydaje się, że w takim stanie rzeczy absolutność „Ty” jest czymś o wiele większym i głębszym od wielości „ty”; jest bowiem sytuacją, w której boskość zdaje się przytłaczać ,ja” powodując w tym ostatnim dojmujące poczucie niższości i zagubienia... Jednak utwór poetki czytać można także w inny sposób. „Ty” przychodzące ze sfery innego, absolutnego daje gwarancję wsparcia „małemu”, ,ja”; daje poczucie bliskości, która ochrania; bliskości, w obecności której ,ja” może czuć się bezpiecznie — skoro „Ty”; każde „TY — to znaczy zrodzone z Absolutnego jest „mocniejsze” w byciu; mocniejsze w istnieniu; mocniejsze w treści, jaką niesie ze sobą. Jest wobec tego wiersz Miłobędzkiej o słabości ,ja”, czy też o wielkości „Ty”; a może o wielkości każdego „Ty”, które jest inne od „,ja”? Trudno w jednoznaczny sposób odpowiedzieć na te pytania. Wchodzą one w strefę niewyrażalnego; wkraczają w obręb tajemnicy.

Ale to nie wszystko. Przyglądając się bacznie utworowi poetki możemy zapytać: w jakiej kondycji jest ,ja”, skoro „każde Ty” jest mocniejsze od niego? Innymi słowy pytamy o — jeśli można ująć to w ten sposób — ,jakość" — ,ja”; pytamy o jego status ontyczny, ale także, a może nade wszystko, aksjologiczny. Słabość „ja” wobec „Ty” wydaje się być konsekwencją utraty stanu „,równości”, statusu równouprawnienia w porządku bytu i wartości. Słabsze ,ja” wobec silniejszego „Ty” wskazuje albo na „ubytek” w sile tożsamości, albo na przejaw ,przemocy”, której stało się ofiarą. Niewyrażalny aspekt tego procesu, którego finalnym efektem jest poczucie „słabości”, w moim odczuciu stanowi jeden z najciekawszych momentów analizowanego utworu. Krystyna Miłobędzka oznajmia nam efekt procesu, który w swej istocie pozostaje tajemniczym, ledwie zarysowanym, pozostającym w przestrzeni domysłu, intuicji, jako niezbędnej w krytycznym instrumentarium interpretatora.

Wiersz ten jawi mi się także, jako wyraz poczucia samotności wobec której „każde Ty” nie musi stanowić gwarancji utwierdzenia w byciu, lecz wręcz przeciwnie, oznacza stan opresji, zagrożenia, niepewności, wyobcowania... Wieloznaczność odczytań tego utworu przekonuje mnie o niewyrażalności jego sensu; o poczuciu nieadekwatności słów i określeń względem zdarzeń i procesów w nim zachodzących. 
Kolejnym niezwykle frapującym utworem jest wiersz Juliana Kornhausera „Widzenie” (Kornhauser 2007: 55)z tomu „Origami”. Jest to utwór zagadkowy. Pod tytułem, po prawej stronie kursywą zapisane zostaje zdanie/ motto autorstwa kardynała Josepha Ratzingera w dwóch wersetach: „,Człowiek, który dowierza tylko własnym oczom, w rzeczywistości jest ślepy”. A potem kilka centymetrów niżej na pustej białej stronie w dolnym lewym rogu opatrzonej numerem „55”, umieszczony zostaje znak graficzny „kropki”. W tym miejscu rodzą się same pytania:

1. Czy rzeczywiście poza mottem, tytułem i numerem strony na białej kartce znajduje się graficzny znak „kropki”?

2. A może jedynie egzemplarz, którego jestem szczęśliwym właścicielem taki znak posiada?

3. Czy moje „widzenie” zapisanej strony numer 55 jest z pewnością takim samym ,widzeniem”, jak każdego innego czytelnika?

4. Czy „kropka” widziana przeze mnie rzeczywiście jest obecna na stronie 55 mojego egzemplarza tomiku Autora „Origami”? ${ }^{9}$.

5. I chyba najważniejsze pytanie: czym jest „kropka”, i jaką rolę pełni względem motta?

Wydaje się, że pierwszą istotną kwestią, na jaką należy zwrócić uwagę analizując utwór Korhausera jest tytuł. W pewnym sensie stanowi on punkt wyjścia i punkt dojścia każdej interpretacji. Mowa jest zatem o „widzeniu”, a więc takim sposobie poznania, w którym angażujemy narząd wzroku nade wszystko, a nie rozumu, czy też myślowego dyskursu. Innymi słowy: aby zrozumieć trzeba zobaczyć. Albo jeszcze inaczej: aby poznać trzeba ujrzeć. Czyli dotrzeć do sensu, do zrozumienia, to nic innego jak u-widzieć; wydobyć z nie-widzenia; ujawnić ukryte. „Widzenie” jest zatem początkiem rozumienia, i widzenie jest jego kresem; celem, zwieńczeniem. Ale jeśli tak, to zobaczona, ujrzana „kropka” staje się pułapką, poznawczą jamą, z której odmętów $\mathrm{z}$ wielkim trudem można będzie się wydobyć. Dlaczego? Tutaj musimy powrócić do motta. Jak przestrzega Joseph Ratzinger, a za nim, jak się wydaje także Julian Kornhauser, wzrok nie są najlepszym narzędziem poznania. Oczom nie należy ufać. Nie można „dać im wiary”, gdyż, no właśnie, w istocie swojej są niewiarygodne. Prowadzą nas na manowce fałszu, mało - czynią nas ślepcami. A ci ostatni nie widzą nic. Przedziwna i zaskakująca jest tutaj logika/antylogika tekstu. „Widzenie” jest ślepotą. Dokładniej: „widzenie” za pomocą „własnych oczu” jest ślepotą. Jednak poeta trochę osłabia przywołaną wyżej tezę. Ratzinger w istocie powiada, że „dowierzanie tylko [podkr.

9 Postanowiłem dokonać eksperymentu i pokazałem 55 stronę tomiku mojej żonie, która potwierdziła istnienie na niej znaku graficznego „kropki”. 
moje - M. D.] własnym oczom" jest ślepotą. Zapytajmy wobec tego, co jest treścią utworu? Czy jest nią znak graficzny „kropki” wyłaniający się z białego tła stronicy 55? A może jest nią tytuł — „Widzenie”, który za pomocą wzroku, którego oczywiście przeceniać nie możemy, gdyż czyni nas „ślepymi”, odczytujemy? A może „Widzenie” jest wezwaniem, apelem do sięgnięcia w rejony niewyrażalnego; w przestrzeń, w której z królewskim gestem rezygnujemy ze wzroku, aby „,przejrzeć' i ,zobaczyć”; aby doznać łaski „,widzenia”; aby przeżyć spotkanie $\mathrm{z}$ „objawiającym się”, przychodzącym ze sfery niewyrażalnego?

O czym zatem mówi nam Kornhauser w „Widzeniu”? Czy mówi nam o złudzeniu wzroku? Czy też o pysze rozumu, który jasno i wyraźnie, po kartezjańsku chciałby ująć świat $\mathrm{w}$ jego wielorakich wyglądach i aspektach? O czym mówi nam „kropka”, którą widzimy? Czy nie jest ona swoistego rodzaju axis mundi - centrum rzeczywistości; jakąś formą najbardziej skondensowanej treści, którą nie sposób „zobaczyć”, ujrzeć za pomocą postrzegania zmysłowego, ale należy sięgnąć głębiej do wewnętrznego wzroku duszy; do przestrzeni niepodległej psycho-fizycznym procesom, i w niej szukać „widzenia”, odnajdywać rzeczywistość w innym, pełniejszym wyglądzie? Pytam, czy „widzenie” jest „kropką”, niezapisaną kartką, czy też bezlitosną diagnozą naszej poznawczej - wzrokowej nieporadności? Być może to jeden z najbardziej niewyrażalnych utworów, w których piętrzą się przed czytelnikiem $\mathrm{i}$ interpretatorem nieusuwalne aporie.

Nie należy „dowierzać” jedynie „własnym oczom”, to znaczy nie wolno zamknąć się w wąskim paśmie doświadczenia zredukowanego do zmysłów. Za „kropką”, zdaje się mówić poeta, jest cały świat, ale my nie jesteśmy go w stanie dostrzec. Musimy zatem ,zamknąć oczy”; musimy zdobyć się na wysiłek porzucenia ,widzenia” na rzecz odzyskania ,wglądu”, ten ostatni jednak może do nas przyjść jedynie na drodze ilu minacji . W ten sposób „widzenie” może stać się zaproszeniem do kontemplacji — już nie będę jedynie dostrzegał czarnej „kropki” na białej stronie numer 55, ale przed „oczami” mojego ducha stanie cały świat i zapyta mnie o własny sens.

Widzenie jest zatem początkiem i kresem procesu, w którym poczynając od kropki, jako znaku graficznego dochodzimy do „kropki” będącej synonimem sensu jako takiego; sensu in spe. Ten ostatni ujawni się (stanie się widocznym) jedynie w akcie kontemplatywnym, w którym fizyczny wzrok nie będzie miał już nic do powiedzenia. „Widzenie” wyjdzie ze sfery niewyrażalnego i będzie tegoż przejawem. Można jednak zapytać skąd pewność, że niewyrażalne, albo „niewidzialne”, czy też nie możliwe do zobaczenia za pomocą zmysłu wzroku wiąże się z kontemplacją? Czy nie jest to z mojej strony przejaw niczym nieuzasadnionej ekstrapolacji? Wydaje się, że wątpliwość tą rozwiać może motto, a raczej osoba jej Autora. Joseph Ratzinger, na którego opinię powołuje się Julian Kornhauser, to postać nietuzinkowa. Przez wielu specjalistów uważany jest obok Karla Rahnera i Hansa Ursa von Balthasara 
za jednego z najwybitniejszych teologów XX wieku10 (Szymik 2010-2015). To właśnie późniejszy papież Benedykt XVI należał do grona najważniejszych architektów Soboru Watykańskiego II. Przez wiele lat u boku św. Jana Pawła II pełnił także funkcję Prefekta Kongregacji Doktryny Wiary, a zatem najważniejszego watykańskiego organu stojącego na straży dogmatycznej poprawności w Kościele Rzymskokatolickim. Odwołanie się przez Autora „Origami”, do Ratzingera postrzegam, jako akt, w którym mamy do czynienia z — jeśli można tak powiedzieć — zasięgnięcia opinii u kogoś, dla którego sensus fidei posiada znaczenie fundamentalne.

3.

stuk-puk

(przez sen,

Od M. B.?)

nic

ości

nie ma

ale coś

$\dot{c}$

$m a$

(być)

(30 czerwca / 1 lipca 1992)

(Krynicki 2009: 377)

Tytuł utworu wskazuje na czynność (stukanie/pukanie), w której ktoś/ coś chciałoby zwrócić naszą uwagę; w której ktoś/coś ujawnia swoją obecność; chce wejść z nami w jakąs interakcję. A zatem możemy powiedzieć, że jest to jakaś forma nawiedzenia, czy też odwiedzin. Ktoś/coś do nas „puka”; chce wejść z nami w jakiś kontakt. Może „niewyrażalne” chciałoby zaistnieć w sferze wyrażonego, albo powiedzmy to w inny sposób: z niewerbalnej sfery przychodzi sygnał nawiedzenia; jakiejś obecności, dzięki której będzie możliwa interakcja z niewyrażalnym. Ciekawią mnie także inne elementy: data umieszczona w nawiasie na końcu wiersza. Być może to zbieg okoliczności, ale jest to data 81 urodzin Czesława Miłosza, niezwykle dla Krynickiego ważnego poety. A inicjały z motta: „M. B.?” — mogą przecież wskazywać na Miłosza właśnie („M”), ale także na Boga („B.?”), zwłaszcza skoro ten drugi opatrzo-

10 Opinię taką głosi min. Jerzy Szymik, autor fundamentalnej, trzy tomowej rozprawy na temat teologii Josepha Ratzingera - Benedykta XVI. Zob. Theologia Benedicta, t. I-III, (Szymik 2010-2015). W motcie wprowadzającym w tom I, J.Ratzinger - Benedykt XVI zauważa: „Wszystkie odpowiedzi, które nie sięgają aż do Boga, są za krótkie”. (Homilia wygłoszona w Monachium, 10.09.2006r.). Por. Theologia Benedicta, t. I, (Szymik 2010: 4). 
ny został znakiem zapytania. W takim razie ten, kto ,stuka/puka przez sen to albo Autor ,Trzech zim”, albo Stwórca ${ }^{11}$. Konsekwencje tego stanu rzeczy wydają się być trudnymi do przecenienia. Oto bowiem poeta doznaje łaski nawiedzenia z sfery niewyrażalnego, które „,przez sen” chce opowiedzieć coś o rzeczywistości; które pragnie oznajmić jakąś prawdę.

Dodajmy, że wiersz Ryszarda Krynickiego być może jest zapisem snu, gdyż na jego oniryczny charakter wskazywać może zapis pod utworem: „30 czerwca/ 1 lipca 1992” a także rodzaj motta umieszczonego w nawiasie: „(przez sen/od M.B.?)”.

Ciekawy dla interpretatora jest także fakt, że cały utwór poeta zapisał kursywą, jak gdyby podnosząc na inny, metasemantyczny poziom. Z trudnością też przychodzi nam znaleźć właściwy klucz interpretacyjny, dzięki któremu będziemy mogli głębiej wejrzeć w jego sens ${ }^{12}$. Mamy tutaj jedną tezę oraz jedno przypuszczenie. Teza głosi: „nic / ości / nie ma”. Natomiast przypuszczenie postuluje, iż „coś(ć) // ma / (być)”. Tak więc rozpięci jesteśmy pomiędzy metafizycznym przekonaniem i eschatologiczną nadzieją. Być może mamy tutaj do czynienia także z intrygującą grą, w której słowo „nicość” zostaje podzielone w dwa inne słowa (,nić” i „ości”), jak gdyby chciano nam zasugerować, że nie można podzielić „nicość”; że jest ona integralną całością w ontycznym tego słowa znaczeniu — a jeśli tak, to „nie ma” jakiegokolwiek możliwego produktem jej podziału.

Wchodzimy tutaj zdecydowanie w rejon niewyrażalnego. „Nicości” „nie ma”, to znaczy wszystko, co posiada choćby jakąkolwiek nazwę, językowy korelat już ,jest”. Oczywiście bytowość może posiadać różne — jeśli można tak się wyrazić — stopnie nasycenia. Może być to bytowość „mocna” — np. przedmiotów świata materialnego podpadającego pod zmysły i weryfikowalnego na pomocą empirycznych narzędzi poznawczych. Może być to także bytowość „słabsza” np. przedmiotów intencjonalnych, jak choćby dzieł sztuki, o których pisał Roman Ingarden w swojej fundamentalnej rozprawie „, $O$ dziele literackim" albo istnienie bytów matematycznych, o których bytowy status trwają dyskusje od czasów Platona, wreszcie sfera przedmiotów „duchowych”, niematerialnych jak choćby istnienie i natura bytów czystych - Aniołów, o których rozprawiali już Filon, Porfiriusz, Jamblich, Proklos, czy też św. Tomasz z Akwinu (Gilson 2003: 191-205).

Dlaczego o tym przypominam. Otóż penetracja tego, co niewyrażalne, a takim jest, jak się wydaje w rozumieniu Krynickiego, zarówno „nicość”

11 Oczywiście mam pełną świadomość hipotetyczności wyżej zaprezentowanych uwag, oraz ich nie-weryfikalności, co jednak nie zmienia faktu, iż również taka ewentualność może być brana pod uwagę, jako jedna z możliwych.

12 Alina Świeściak zauważa: „Brak jest tu albo pozorem (pierwszy tekst), albo grą zaprzeczeń (tekst drugi). To, co pozbawione zmysłów - (naprawdę) Jest. Niepojęte to nie brak, ale (Blake’owska) nieskończoność. Nicość rozbita na $<$ nic $>$ i $<$ ości $>$ nie jest przesadnie przerażająca, poza tym z resztki po niej wzięła się <ćma>, a więc jednak <coś>". Wymiary pustki. Ryszard Krynicki, (Świeściak 2010: 146). 
(której nie ma), jak również „coś”, co jest; a raczej „ma być”. I ten moment wydaje mi się najbardziej tajemniczy. Ważniejsze z ontycznego punktu widzenia jest to „,o ma być”. A co ma być - możemy zapytać? Tego nie wiemy! Jednak mocne przekonanie o trwałości bytu, dopowiedzmy bytu, który transcenduje swoją empiryczną naturę w stronę rejonów innych, „niepodległych nicości", żeby użyć tytułu jednego z poetyckich zbiorów Krynickiego (Krynicki 1989) wskazywać może na otwarcie bytu na jego duchowy wymiar.

W słynnym, pomieszczonym w tomie „Wiersze, głosy” z 1987 roku, enigmatycznym wierszu bez tytułu, posiadającym tylko dwa słowa: „nic, Bóg”, równie ważnym, integralnym jego składnikiem wydaje się być motto: „z Mistrza Eckharta, czy Księgi Zohar?”. A zatem Ryszard Krynicki wskazuje na dwie tradycje mistyczne: chrześcijańską mistykę Eckharta oraz fundamentalne dzieło XIII wiecznej żydowskiej kabały — „Księgę Zohar” — „Księgę Blasku”. Gershom Scholem zastanawiając się nad kabalistyczną koncepcją boskich potencji, czyli sefirot, dzięki którym Bóg się ujawnia, dochodzi do wniosku, iż możliwa przerwa między przejściami od jednej do drugiej potencji, przyjęta przez żydowskich mistyków ,,[...] nicość prapoczątku, mogłaby [...] tkwić jedynie w samej istocie Boga. [...] Chaos, wyeliminowany w teologii $<$ stwarzania $\mathrm{z}$ niczego $>$, pojawia się na powrót w nowej metamorfozie. Owa nicość istniała w samym Bogu zawsze [podkr. moje - M.D.], nie poza nim i nie przez niego wzbudzona. Jest nią, koegzystująca z nieskończoną pełnią bóstwa, otchłań w Bogu, pokonana w akcie stworzenia [...]" (Scholem 1996: 114). A skoro tak, to rzeczywiście możemy postawić znak równości między nicością i Bogiem ${ }^{13}$. W ten sposób zarówno „Bóg jest nicością” skoro ta ostatnia stanowi integralny komponent jego natury, jak i „nicość jest Bogiem”. Ontologicznie zatem nie możemy wyjść poza pełnię Bytu, którym jest Bóg, i poza jego zaprzeczenie, jakim jest nicość. W ten sposób podważona zostaje zasada tożsamości, która powiada, że byt jest samym sobą.

Warto wspomnieć, iż Mistrz Eckhart w „Kazaniu 13” powiada:

Największą rzeczą, której człowiek może się wyrzec, jest wyrzeczenie się Boga dla Boga. Otóż święty Paweł wyrzeka się Boga dla Boga; wyrzeka się on wszystkiego, co mógł wziąć od Boga, i wyrzeka się wszystkiego, co Bóg mógł

13 Warto dodać, że w kosmogonicznym micie Zoharu nicość zostaje zastąpiona przez aurę światła. Warto zacytować fragment Księgi Blasku: „Na początku, gdy wola króla zaczęła działać, wyryła ona znaki w niebiańskiej aurze. $Z$ najbardziej ukrytej sfery w tajemnicy nieskończoności wyłonił się ciemny płomień niczym mgła, która tworzy się w bezpostaciowości, wpuszczony w krąg [owej aury], nie biały i nie czarny, nie czerwony i nie zielony, i w ogóle bezbarwny. Dopiero po przybraniu wymiarów przestrzennych ów płomień wydał błyszczące kolory. W samym wnętrzu płomienia powstało mianowicie źródło, z którego kolory rozlewały się na wszystko w dole, ukryte w tajemnych sekretach nieskończoności. Źródło przebijało otaczający je eter, ale go nie przebiło, i było zupełnie niepoznawalne, dopóki wskutek impetu jego przebicia nie rozbłysnął ukryty najwyższy punkt. Poza tym punktem nie da się niczego rozpoznać, i dlatego zwie się on reszit i jest pierwszym słowem stwórczym z dziesięciu, przez które stworzony został Wszechświat" (Scholem 1996: 115). 
mu dać, i wszystkiego, co mógł od Boga otrzymać. Wyrzekając się tego, wyrzeka się Boga dla Boga, a wtedy pozostaje mu Bóg taki, jaki istniejąc jest sam w sobie, a nie na sposób, w jaki jest przyjmowany czy osiągany, lecz w bytowości, którą Bóg jest sam w sobie. Nigdy nie dał on Bogu niczego ani nie otrzymał niczego od Boga; jest jednym i czystą jednością. Tu człowiek jest prawdziwym człowiekiem; a tego człowieka nie może spotkać żadne cierpienie, tak jak nie może ono spotkać żadne cierpienie, tak jak nie może ono spotkać boskiego bycia. (Eckhart 1988: 186).

Między „nicością” a „Bogiem” jawi się przestrzeń tego wiersza. A zatem pomiędzy możliwie najdalej rozsuniętymi skrajnościami ontycznymi. Przepaść miedzy „nicością” i „Bogiem” ledwie zaznaczona „przecinkiem”, to przecież przestrzeń rzeczywistości, w której umieścić można wszystko, co nazywamy światem. Niewyrażalność świata jest zatem schowana w „przecinku”; zakotwiczona w „pauzie" między Bogiem i nicością. Warto tutaj zwrócić uwagę na jeszcze jeden niezwykle istotny fakt: zarówno rzeczywistość nicości, jak i rzeczywistość Boga są „mocne” w porównaniu z rzeczywistością „przecinka”, która jest „słaba”, ledwie „przejawiająca się”, znikoma. Ale to przecież w niej — o paradoksie — zawarty jest cały świat!

\section{4.}

W tomie „Jeden” Marcin Świetlicki pomieścił utwór „Przeprowadzka” $\mathrm{z}$ ło do bro.

(Świetlicki 2013: 55)

Oto niezwykle enigmatyczny zapis wiersza, który może być zarówno tezą, uznaniem aksjologicznego porządku (w świecie, w którym na każdym kroku wszelkie wartościowanie doznaje gwałtu ze strony postmodernistycznej ideologii), wyznaniem, a wreszcie jakąś formą katharsis... Tytuł wskazuje na ruch podobny do tego, który jest charakterystyczny dla zmiany zamieszkania - wtedy bowiem ma miejsce ,przeprowadzka”. A zatem jest tutaj zasygnalizowany jakiś ruch. Przeprowadzamy się na inne miejsce, do innego mieszkania, domu, miasta, kraju, czy też na inny kontynent. Ale jedno w przeprowadzce pozostaje niezmienne: to, co było już nie jest takim teraz - nastąpiła zmiana; coś bezpowrotnie utraciliśmy, a coś teraz jest inne, nie takie same jak do tej pory. „Przeprowadzka” wymusza zmianę; jest jakąś formą „śmierci” starego, i rozpoczęciem ,życia” nowego; jest wyjściem ze starego i wejściem w nowe; jest opuszczeniem jakiegoś domostwa, zadomowienia, jakiejś ,„przytulności”, albo „bezdomności” i nowym zamieszkaniem, wejściem w przestrzeń innego niż byłe; innego niż opuszczone. W ,przeprowadzce” zawsze coś zmieniamy — i zawsze w coś wchodzimy; zawsze coś opuszczamy, aby coś innego posiąść. 
O czym zatem pisze Świetlicki w swojej „,Przeprowadzce”? Z jaką formą przenosin mamy w wierszu tym do czynienia? Co się w tej przeprowadzce opuszcza i do czego się wprowadza?

Poeta poprzez rozstrzelenie liter tworzących wyrazy: „dobro” i „,zło”, daje nam wskazówkę ruchu „,z” do „do”. A zatem mamy jasno zarysowany punkt wyjścia - jest nim „zło”, oraz punkt dojścia, którym jest „,dobro”. Jest to zatem „ruch” natury etycznej; ruch moralny, w którym mowa jest o fundamentach aksjologicznych kultury świata Zachodu. „Przeprowadzić” się ze „zła” do „,dobra”, to tyle, co porzucić niemoralny, łamiący zasady etyczne sposób życia i z dobra uczynić horyzont swojego postępowania. To wejść na ścieżkę innego sposobu usensownienia własnej egzystencji, gdzie dobro stanie się jego aksjologicznym, sensotwórczym horyzontem. W tej perspektywie „,Przeprowadzka” jawi się, jako wiersz (choć w swojej językowej strukturze tak niezwykle oszczędny, ascetyczny) o skondensowanym go granic możliwości ładunku aksjologicznym.

Esencjalnie moglibyśmy powiedzieć, że nie ma innej rzeczywistej „przeprowadzki", jak ta, która dokonuje się w przestrzeni aksjologicznej. Jest tylko jedna, najbardziej właściwa, esencjalna ,przeprowadzka” — to ruch „od” zła, do „dobra”. A jeśli tak, to element niewyrażalnego tkwi właśnie w owej zmianie, w subtelnym momencie opuszczenia zła, i przylgnięcia do dobra. Niewyrażalność jest w istocie swojej synonimem ,,przeprowadzki” -oto pojęcie pierwotne, aporetyczne, niedefiniowalne, w którym przez moment ujawnia się samo niewyrażalne. Ów moment ,zawieszenia”, pauzy między opuszczanym złem, a jeszcze nie przyjętym dobrem — stanowi przejaw niewyrażalnego.

\section{BIBLIOGRAFIA}

Balcerzan Edward. «Niewyrażalne czy nie wyrażone». Teksty Drugie 3/45 (1997): 5-19.

Mistrz Eckhart. Kazania i traktaty, tłum. J. Prokopiuk. Warszawa: Instytut Wydawniczy PAX, 1988.

Gilson Etienne. Tomizm. Wprowadzenie do filozofii św. Tomasza z Akwinu, tłum. J. Rybałt. Warszawa: Instytut Wydawniczy PAX, 2003.

Kluba Agnieszka. «(Do)wolność niewyrażalności». Teksty Drugie 3/45 (1997): 119-129.

Kornhauser Julian. Origami. Kraków: Wydawnictwo Literackie, 2007.

Krynicki Ryszard. Niepodlegli nicości. Wybrane wiersze i przekłady. Kraków: Wydawnictwo Znak, 1989.

Krynicki Ryszard. Wiersze wybrane. Kraków: Wydawnictwo a5, 2009.

Miłobędzka Krystyna. Gubione. Wrocław: Biuro Literackie, 2008.

Przybylska Nelly. «Ujrzeć niewyrażalne: o językowej etyce u Levinasa». Sztuka i Filozofia 38-39 (2011): 101-109.

Szymik Jerzy. Theologia Benedict, t. I-III, Wydawnictwo św. Jacka: Katowice 2010-2015.

Scholem Gershom. Kabała i jej symbolika. Przeł. R. Wojnakowski, Kraków: Wydawnictwo Znak, 1996.

Świeściak Alina. «Wymiary pustki». Ryszard Krynicki. Świeściak Alina. Melancholia w poezji polskiej po 1989 roku. Kraków: Universitas, 2010.

Świetlicki Marcin. Jeden. Kraków: EMG, 2013.

Wittgenstein Ludwig. Tractatus logico-philosophicus. tłum. B. Wolniewicz. Warszawa: Wydawnictwo Naukowe PWN, 2000. 
Мирослав Ђењ

\section{КАТЕГОРИЈА „НЕИЗРЕЦИВОГ“ У КРИТИЧКО-КЮИЖЕВНОМ ДИСКУРСУ (РИШАРД КРИНИЦКИ, КРИСТИНА МИЛОБЕЦКА, ЈУЛИАН КОРНХАУСЕР, МАРТИН СВИЈЕТЛИЦКИ)}

\section{Резиме}

У раду покушавамо да опишемо категорију „неизрецивог“ на граници критичко-књижевног и теолошког дискурса. Анализирани су радови Ришарда Криницког, Кристине Милобецке, Јулиана Корнхаусера и Мартина Свијетлицког. У круг анализираних стихова може се укључити шири контекст који обухвата филозофију дијалога Мартина Бубера, јеврејску кабалу или, пак, мистику Мистра Екхарта. Неизрециво се кристалише као архетипски појам који се налази на другом - онтичком и аксиолошком - нивоу. Неизрециво се може лоцирати у сфери широког појмовног смисла мистичког. Неизрециво се појављује увек као „надградња“ изрецивог; као форма допуњавања света. То, свакако, има додирних тачака с интуитивним дискурсом и покушајима да се конструишу још тешње везе међу њима. Категорија „неизрецивог“ је недефинисан појам, апоретичан, у којем се скрива тајни смисао.

Кључне речи: неизрециво, мистика, филозофија, јеврејска кабала. 